\title{
A magyar légtérellenőrzés jövőbeni müszaki kihívásai
}

\section{ELŐZMÉNYEK}

Az első, teljesen magyar fejlesztésű távolfelderítő rádiólokátorok 1943. december 20-án, Sári község közelében léptek hadműveleti szolgálatba. [1] A SAS radarok a „m”-es „VHF” hullámtartományban 120 MHz-en üzemeltek. Néhány adat a legfontosabb műszaki paraméterek közül: szimmetrikus táplálású passzív fázisvezérelt antennarács, $10 \mathrm{~kW}$ impulzusteljesítmény $8 \mu \mathrm{s}$ impulzusszélesség és $750 \mathrm{~Hz}$ impulzusismétlődési frekvencia mellett. A vízszintes antennanyaláb szélessége 22,5 fok volt, amely az oldalszög mérési pontosságának növelésére kiegészült monopulzusos irányméréssel. A szabadtéri maximális céltárgy detektálási távolsága Liberator típusú bombázó repülőgépre - amelyet $10 \mathrm{~m}^{2}$-es hatásos visszaverő felülettel rendelkező céltárgyként alkalmaztak - 136 km volt. Ebben az időben ismerték fel, hogy a méteres hullámtartomány-

1. ábra. A SAS-1 és SAS-2 radarok települési körzete ${ }^{1}$ [1]

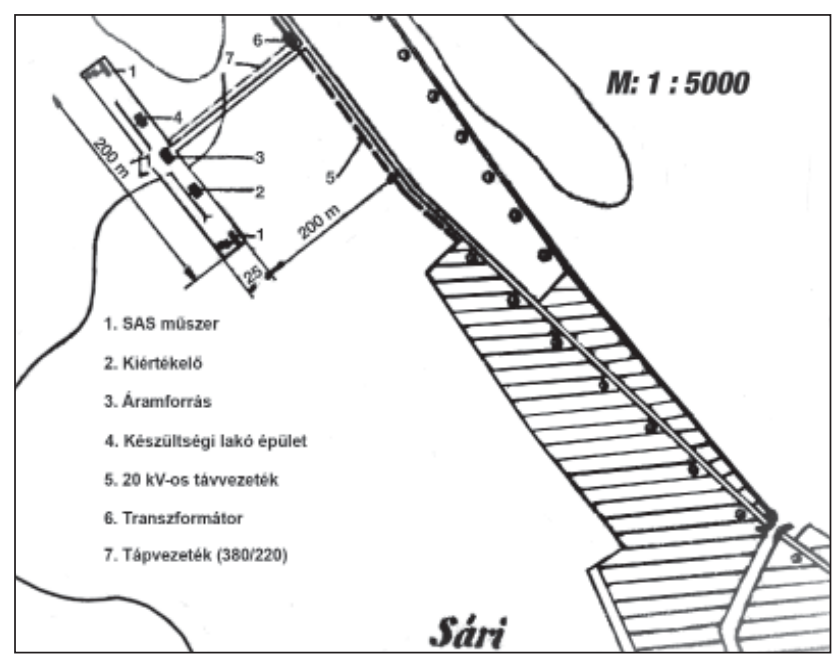

ÖSSZEFOGLALÁS: Az a tény, hogy Magyarország a Kárpát-medence közepén helyezkedik el, sajátos elvárásokat támaszt úgy a polgári, mint a katonai légtérellenőrző rádiólokátorokkal szemben. A környezetünkben található magas hegyek miatt más országokban telepített radarok elvárásaihoz képest jelentősen intenzívebbek a passzív zavarok és az interferencia jelenségek is gyakoribbak. A rádiólokációval kapcsolatos történelmi, üzemeltetési, kutatásfejlesztési tapasztalataink részben eltérnek más országokétól. A technológia fejlődésével új kihívások jelentkeznek, amelyek közül a legfontosabbak a különböző típusú drónok miatt megjelenő veszélyek, vagy az alacsony Föld körüli pályákon keringő müholdak interferencia jeleinek időbeni észlelése. A cikk a korszerú rádiólokátor technológiákkal kapcsolatos magyar sajátosságokra, lehetőségekre hívja fel a figyelmet.

KULCSSZAVAK: légtérellenőrzés, radar-rendszerek, pilóta nélküli repülőeszközök, kutatás-fejlesztés ban a földreflexió megnöveli a céltárgyak maximális detektálhatóságát - e konkrét esetben kb. 200 km-re.

Az 1. ábrán látható, hogy két azonos típusú radar egymástól 200 m-re települt. Az egyik radar percenként háromszor tapogatta le 200 km-es környezetét, míg a másik radar csak adott szektorokban pontosította a célok helyzetét, illetve az elfogó vadászokat vezette célra. Jelentések bizonyítják, hogy a radarkezelők 500 km távolságról visszaverődéseket vettek az Alpok hegyeiről, illetve a felettük repülő Liberator kötelékekről. Ennek műszaki magyarázatát csak napjainkban, a gaussi monostatikus rádiólokációval kapcsolatos kutatások adták meg. A lényeg, hogy lehetséges két egymás közelében települt rádiólokátor adóteljesítményének összegzése a céltárgy felületén, a kisugárzott és a céltárgyról visszavert jelek mindkét antennával történő erősítése az azonos irányokból érkező jelek térbeli szűrésével és közös integrálásával. Ennek következtében a céltárgyak maximális detektálhatósága az egyenes rálátás határain belül megkétszerezhető. Ez a képesség még napjainkban is gyakran hiányzik a világ nagy radargyártóinak berendezéseiből, vagy azért, mert nem ismerték fel a lehetőségeket, vagy egyszerűen nem adhatják el külföldre ezt a technológiát.

Napjainkra a különböző típusú radar- és navigációs rendszerek világviszonylatban meghatározó jelentőséggel bírnak a kereskedelmi, a polgári, a határvédelmi, a katasztrófavédelmi, a rendvédelmi, a terrorelhárítási és a katonai légi forgalom központi és autonóm irányításában egyaránt. Különösen jelentős kockázat merülhet fel a polgári célú eszközöknél, amelyek a nem együttműködő, nagyon kis radarkeresztmetszettel (RCS) és nagy manőverező képességgel rendelkező repülőeszközök detektálására nincsenek felkészítve.

\section{NAPJAINK KORSZERŰNEK TARTOTT RÁDIÓLOKÁCIÓS TECHNOLÓGIÁI}

Fázisvezérelt antenna alkalmazása: Legfontosabb előnye, hogy lehetőséget ad az antennanyaláb gyors elektromos mozgatására. Ezáltal adott/elvárt térrészeket hosszabb
ABSTRACT: The location of Hungary of being in the middle of the Carpathian Basin generates specific requirements for the civilian and military air traffic control radar performances. The surrounding high mountains in our vicinity generate more intensive passive and interfering phenomena compared to other countries radar systems. Our historical, operational and R \& D experience on radars is different from other countries. As technology moves ahead, new challenges arise, among which the most important is created by the different types of drones or by low-earth orbiting satellites producing interference signals, which are very hard to be detected in time. This article draws attention to the Hungarian peculiarities and to the possibilities of advanced radar technology.

KEY WORDS: air traffic, radar systems, unmanned air vehicles, advanced radar technology 


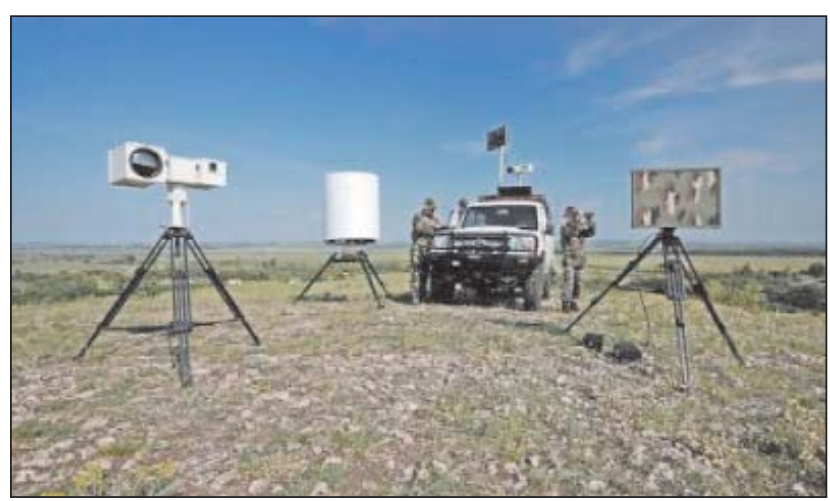

2. ábra. A Pro Patria Electronics adaptív többérzékelős rendszere

ideig, nagyobb energiával, illetve gyakrabban világíthatjuk meg. Legfejlettebb típusaik gyorsan változó paraméterekkel, irányok, nyalábszélesség és oldalnyalábszintek, digitális antenna-iránykarakterisztika kialakítását biztosítják. Legnagyobb hátrányuk az elektromos nyalábmozgatáskor fellépő magas oldalnyalábszintek, amelyek közeli állócélok vagy interferencia esetén intenzív hamis célképződések kialakulásához vezetnek. Az antennanyereség és irányszélességi szög az antenna felületétől függ, amely a napjainkban rendszerben lévő távolfelderítő radarok esetén 10003000 sugárzó az „L" sávú, míg 5000-10 000 elem az „S” sávú radarok esetén. Az adóteljesítmények 2 és $10 \mathrm{~kW}$ közöttiek, amelyek vagy az antennarendszer mögött szerelt modulokban, aktív fázis antennaként vagy, passzív fázis antenna esetén külön adókabinban találhatók. A két megoldás közötti különbségek az antenna infra(hő) képe, a nagyfrekvenciás jelek veszteségeiben és a 15-20 évre számított logisztikai költségekben jelentkeznek. A hőelvezetés problémájának nagyságát jelzi, hogy napjainkban több helyet foglalnak el a ventilátor és egyéb hőelvezető egységek, mint maguk a nagy teljesítményt előállító berendezések. A jelenlegi legfontosabb fejlesztési irányok az elemi antennasugárzók méretének csökkentése, számuk jelentős 3-5-szörösére növelése és a sugárzók rész- vagy modulárisan változtatható méretű antennacsoportokba szervezése. Ezáltal a több, párhuzamosan előállított iránykarakterisztika miatt az antennanyereség nő, az oldalnyaláb szintek csökkennek, az aktív zavarvédelmi képességek növelésének lehetőségei és a nyaláb mozgatás szabadságfoka nőhet. Kutatások folynak annak érdekében, hogy speciális antennafelületekkel csökkenthetők legyenek az iránykarakterisztika oldalnyalábszintjei. Kiemelt feladat a jelenleg alkalmazott adórendszerek teljesítményének 3-6 szorosára növelése a hatásfok növelése mellett, pl. gallium-nitrát alapú félvezető modulokkal, a veszteségek csökkentésével. Az utóbbi elvárás egyértelműen az űrtechnológia rádiólokátorokban való térhódítását jelenti.

\section{KIS FÁZISZAJÚ, KIS VESZTESÉGEKKEL RENDELKEZŐ RÁDIÓFREKVEN- CIÁS EGYSÉGEK INTEGRÁLT ALKALMAZÁSA}

Ez a típusú felhasználás két fő területen elvárt:

1. Rádiólokátor alapjel-előállító, az adó- és vevőrendszerben az RF jel teljesítmény erősítésére.

2. Az analóg/digitális jelfeldolgozás kapcsolódási felületén, ahol a jel torzítását és a RF jelfeldolgozás veszteségeit alacsony szinten kell tartani. A feladat legnagyobb kihívása, hogy az aktív és passzív zavarvédelem szempontjából rendkívül kritikusan kell kezelni az elvá-

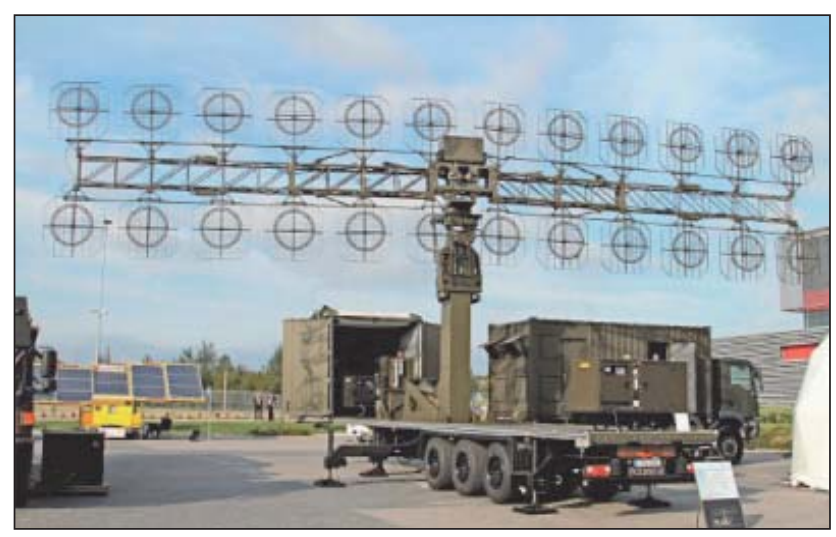

3. ábra. Lengyel gyártmányú Amber-1800-as VHF radar

rásokat, illetve az azokra javasolt analóg megoldások jeltisztaság rontó hatásait. Ezért kiemelt figyelmet kell fordítani az új típusú pl. változtatható dielektrikummal rendelkező anyagok radarokba történő beépítésére (pl. a 3D nyomtatók nyújtotta lehetőségek kihasználása).

\section{A DIGITÁLIS JELFELDOLGOZÁS ÉS A SZOFTVER RADAR NYÚJTOTTA LEHETŐSÉGEK SZÉLESKÖRŰ ALKALMAZÁSA}

Napjainkban már kidolgozott megoldások léteznek az analóg jelek digitális jelsorozattá, valamint a digitális információ analóg jelekké történő alakítására. A fejlődés a mintavételezési frekvencia és a feldolgozott jelek dinamikájának növelésében jelentkezik, ez napjainkban 16 bites felbontással 300-900 MHz mintavételt alkalmazó megoldásokat tesz lehetővé. A következő lépésben a nagy mintavételezési sebességgel gyűjtött jeleket szűrik, átlagolják, és a Shannon-tétel elvárásainak megfelelően célhardverek segítségével osztályozzák, előkészítik a további jelfeldolgozás számára. Több vételi csatornán párhuzamosan érkeznek az adatok, ezért a jelkésleltetések fázis- és amplitúdókorrekcióit a minél hatékonyabb korrelációs jelfeldolgozás érdekében folyamatosan biztosítani kell. A ma korszerűnek tartott radarokban az oldalnyalábokon keresztül vett impulzus-, néhány esetben zajzavarokkal kombinált, zavarok elleni védelem megelőzi az impulzus kompressziós szűrőket, amelyek ma már szinte kizárólagosan adaptív digitális megoldások. A hamis és valós céljelek elkülönítéséhez alapvető elvárás, hogy kihasználják a radarban történő jelelőállítás flexibilitásában meglévő lehetőségeket. Ezért a radar különböző, akár több frekvencián párhuzamosan futó belső modulációval rendelkező impulzusokat sugároz ki, amelyekre a vételi szakaszon hatékony illesztett szűrőket alkalmazhatunk az optimális jel/(zaj+zavar) viszony előállítására. Ezeknek az elvárásoknak megfelelő jelek teljesítménye minimális veszteségekkel az adórendszerben eléri az elvárt szintet, majd az antennán keresztül kisugárzásra kerül az éppen vizsgálat alatt lévő térrészbe. Az igazán korszerű radarok pl. a „lopakodó” tulajdonságokkal rendelkező céltárgyak detektálására „céltárgyra optimalizált” adójel-modulációkat alkalmaznak.

A vett jelek teljesítményét jelösszegzéssel növeljük, majd mozgócél-jelző (Moving Tartget Indicator - MTI) vagy mozgócél-kiválasztó (Moving Tartget Detector - MTD) és negatív visszacsatolással rendelkező adaptív passzív zavartérkép algoritmusokkal a hasznos céljeleket elkülönítjük a hamisaktól. A célok detektálása adott elvárások szerinti követelményeinek biztosítását a konstans vaklárma normalizáló (Constant False Alarm Rate Normalizer - CFAR) 
szubrutinok végzik. A plot extractorok feladata a helyszögben és oldalszögben különböző csatornákban detektált céljelek „összefűzése” egyetlen, távolság, oldalszög, helyszög/magassággal és radiális sebességgel (ha rendelkezésre áll) jellemzett plot jelentéssé. Ezeknek a jelentéseknek a céltárgyak kinematikus jellemzőivel behatárolt „rendezésével" készül az útvonal, amelyre már feladatokat lehet képezni. Ez a folyamat minden radarban többé-kevesebbé sikeres formában megvalósul. Minden ezen túlmutató felhasználói elvárás, pl. az új kihívások kezelése, külön fejlesztést igényel.

\section{KoRSZERÜ, 15-20 ÉVEN KERESZTÜL BIZTOSítHATÓ LOGISZTIKA- ÉS RADARÜZEMKÉPESSÉG-TÁMOGATÁS KAPCSÁN FELVETŐDŐ KÉRDÉSEK}

Ezen a területen jelentős tapasztalatokat szereztek a magyar légtérfelügyeletért felelős szakemberek. Ugyanakkor a korszerű rádiólokátor-rendszerek költséghatékony megszervezése területén jelentős a lemaradás. A fő probléma az, hogy a nemzetközi tenderek esetén a pályázóknak - ha nyerni akarnak - a minimális felhasználói-műszaki elvárásokat, minimális áron kell kínálniuk. (Előfordul, hogy a gyártó különböző állami forrásokból kap támogatásokat a radar $\mathrm{K}+\mathrm{F}$ tevékenység versenyképességének növeléséhez, ezzel munkahelyeket teremt és tart fent hosszú időn keresztül.) Így azonban csak a radar 15-20 éves élettartamciklusán keresztül lehet nyereségre szert tenni, amely tapasztalatok szerint a radar vételi árának 4-7 szerese. Ezen a helyzeten valamelyest segíthet az eredeti gyártóval kötött fix peremfeltételekkel rendelkező, élettartamra szóló logisztikai támogatási szerződés, amennyiben kiváló szakjogászok segítik annak elkészítését. Ugyanakkor a szerződések „vis maior” kivételei, az üzemeltetés során bekövetkező felhasználói követelmény-kiegészítések, a saját kezelőállományunk üzemeltetés során megmutatkozó hiányosságai azok a területek, amelyek a gyártó számára az extraprofit elérését biztosítják. Jelentős költségek takaríthatók meg a radarok professzionális logisztikai kiszolgálásával, amely folyamat elvárja, hogy:

- az üzemeltetett radar beépített működésfelügyelő rendszere pontosan előre jelezze a meghibásodások pontos helyét;

- a kezelőállomány értse is a radar működését ne csak felügyelje;

- rendszeres időközönként az eredeti gyártótól független radar performancia vizsgálatra kerüljön sor, amely lehetőséget nyújt a performancia elvárt szinten tartására és a nagy értékű, nagy üzemidő kieséssel járó meghibásodások előre jelzésére.

Rádiólokátor-vásárlás esetén néhány jó radarszakemberekkel rendelkező ország megvásárolja a radart üzemeltető szoftverek forráskódját is. A szoftverek karbantartásával a radar élettartamára szóló logisztikai költségeinek (beleértve a nagyjavítások és a felhasználó által igényelt feljavítások, újítások beépítését is) kedvező és szabályozott kereteken belül tartására nyílik lehetőség.

A rádiólokátor-parkunkat az 1990-es évek elejétől csak hazai fejlesztésekkel lehetett fenntartani, illetve csatlakoztatni a nyugati típusú adatkapcsolati protokollokkal rendelkező rádiólokációs hálózatokhoz. Ebben a munkában kiemelt szerepet játszottak a HM Arzenál Zrt., a Sky-Soft Kft. és a MIKI (ma Pro Patria Electronics) munkatársai. Közremüködésükkel megoldódott minden, rendszerben lévő radar jelfeldolgozó rendszerének jelentős korszerűsítése, a számítástechnikai platformok lecserélése és a repülési tervek valós időben történő információmegosztása a fel-

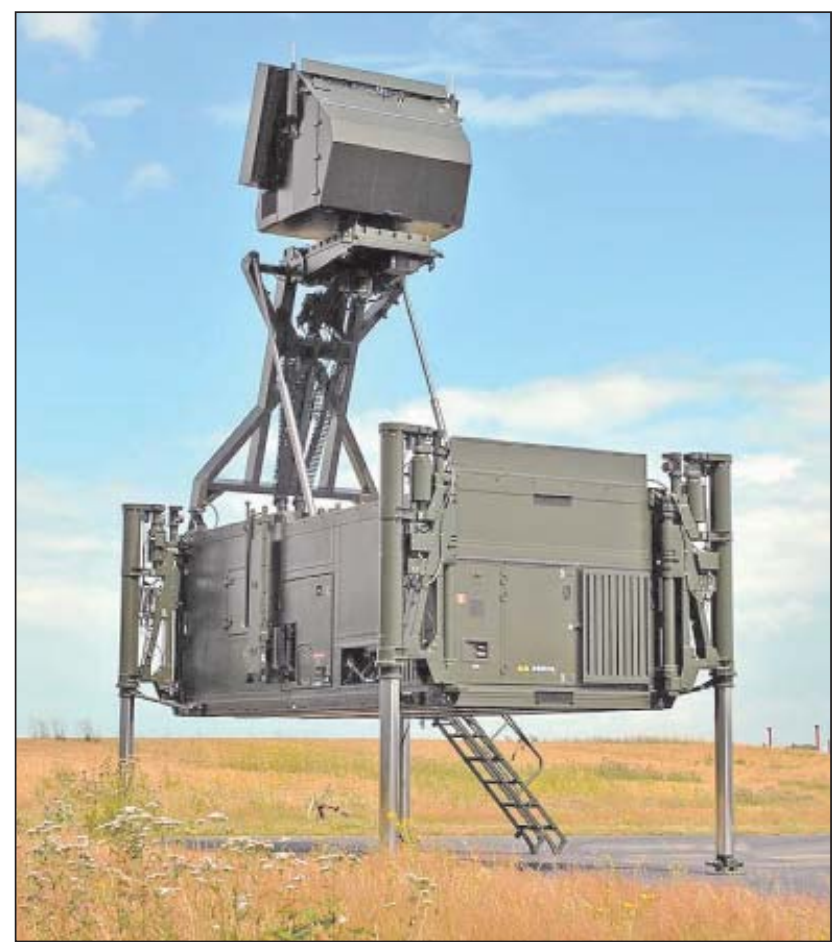

4. ábra. Ground Master 400-as teleszkópos lábakon

használók között. Napjainkban mindhárom cég jelen van a rádiólokációval kapcsolatos nemzetközi piacokon (2. ábra). Erőforrásaink felmérésekor nem szabad elfeledkezni a kisebb közremüködőkről sem, mint pl. a BHE Hungary és a BME Mikrohullámú Tanszék, ahol a radarperformanciamérésekhez elengedhetetlen világszínvonalú tesztberendezéseket, és az "S” frekvencia sávban, nagyon jó hatásfokkal üzemelő adórendszereket fejlesztettek ki.

\section{A RÁDIÓLOKÁCIÓS RENDSZEREKKEL SZEMBEN MEGJELENŐ LEGFONTOSABB ÚJ KIHÍVÁSOK}

A gazdasági, hobbi, illetve polgári felhasználású drónok elterjedésének száma elérte azt a határt, ahol a törvényi szabályozás mellett már lépéseket kell tenni a légtérben történő mozgásuk ellenőrzésére is. A hasznos rádiólokációs felületük változatossága, nagy gyorsulási és dinamikus mozgási paramétereik rendkívül megnehezítik detektálásukat, azonosításukat és útvonalba fogásukat. Ha az adott drónt detektálják is, a jelenleg alkalmazott útvonalképző algoritmusok kiszűrik ezeket a követendő célok listájából, így megszűnik annak lehetősége, hogy aktívan reagáljunk jelenlétükre.

A légi forgalom sűrűségének növekedése mellett, ez olyan további kockázatnövelő tényezőt jelent, amely a légiforgalmi irányítási szolgáltatás biztonságára kedvezőtlenül hat, ezért a primer rádiólokáció a polgári légiközlekedés számára is felértékelődik.

A Föld körül keringő műholdak száma és alkalmazásuk sokszínűsége szembetűnően növekszik, ám némely eszköz olykor letér a pályájáról. A magyar rádiólokátorok talán az egy „Oborona-14” (Tall King C) típusú távolfelderítő radarunkat kivéve - nincsenek felkészülve a detektálásukra és a világűrből érkező interferencia-zavarokra. Napjainkban általános a digitális műholdas tévé/rádió műsorszórás és kommunikáció, amelynek spektruma fehérzaj szerű. A probléma abban áll, hogy a radarantenna függőle- 


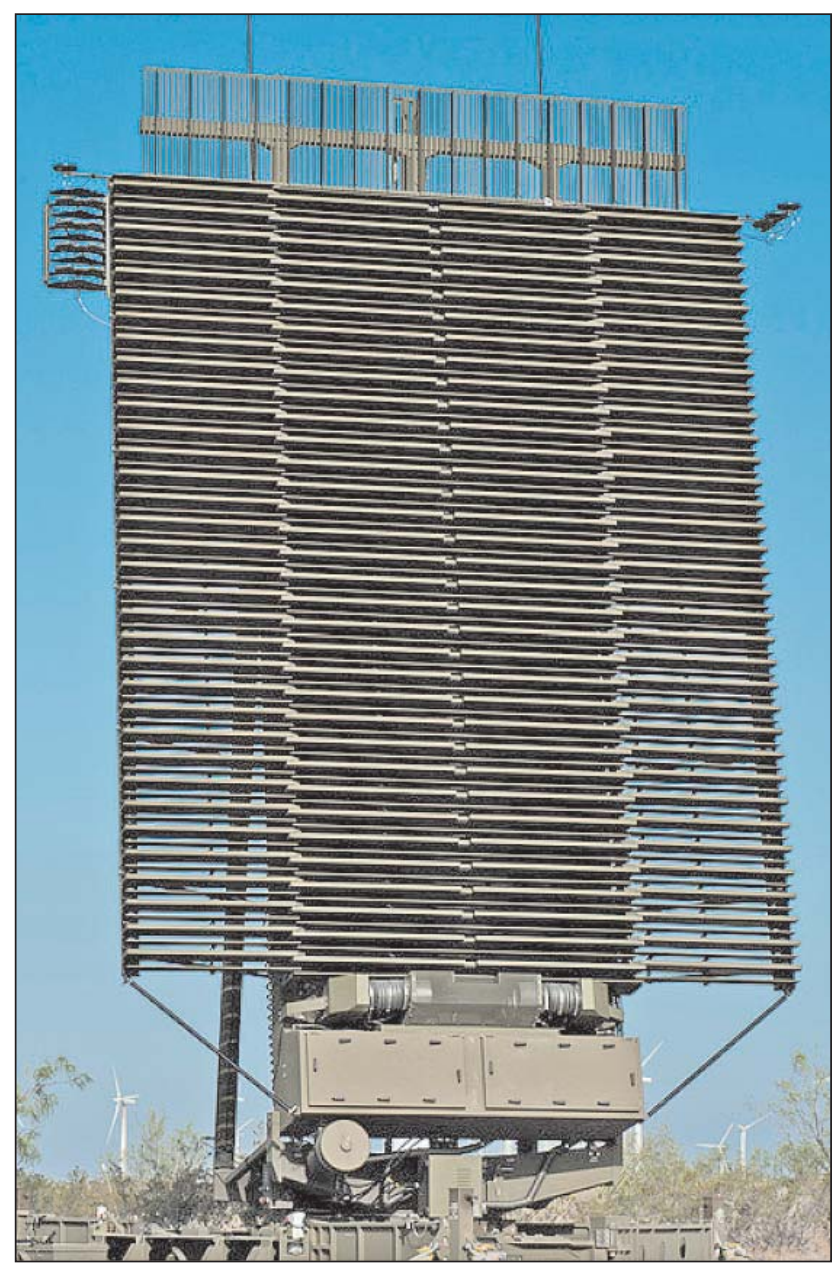

5. ábra. Locheed Martin TPS-77-es mobil radar harcászati ballisztikus rakéta-észlelési képességekkel

ges iránykarakterisztikáján keresztül vett interferenciajel hozzáadódik a radar vevőrendszerének saját zajához, így csökkentve a céltárgyra elvárt jel/(zaj+zavar) viszonyt. Ennek következtében a céltárgyak detektálása később történik, és ennek valódi okáról a kezelőknek nincs tudomásuk. Manapság már léteznek összetettebb és hatásosabb zavarási formái is a műholdas technológiának.

A digitális hírközlés földfelszíni viszonyok között is széleskörüen terjed. Nem csupán a hazai, hanem a környező országok interferencia forrásai is hatnak a rádiólokátorok vevőrendszereire. Ennek következtében a kis rádiólokációs visszaverő felülettel rendelkező céltárgyak detektálása elhúzódik és intenzív interferencia-források irányában gyakran be sem következik. Az ilyen típusú zavarhatás ugyanaz, mint müholdas társaik esetén, azzal a különbséggel, hogy ebben az esetben a zavarforrás irányát meg tudják állapítani a radarok.

A közeljövő rádiólokátorai egyre inkább szoftver alapúak lesznek. A lehetőségek az IT technológia terjedésével rendkívül gyorsan nőnek, így 5-8 év megújulási idő várható a radar performanciák elvárásainak területén. A kibertámadások veszélyének csökkentése érdekében a radarokban használt, polcról levehető számítástechnikai eszközök és hálózatok védelmét tökéletesíteni kell.

Számolnunk kell az urbanizáció ma még pontosan be nem határolható, radarokra gyakorolt hatásaival is. Ilyenek például a rádiólokációs frekvenciák állami eladása (pl. Olaszország, Nagy-Britannia esetében). Ennek következté- ben a radarnak - többek között - a jogszabályok nem biztosítnak monopóliumot az adott frekvenciasávban, így nem okozhat interferenciát és el kell „tűrnie” ha zavarják. A szélerőművek terjedése is töretlen, amelyeknek a rádiólokátoros felderítésre gyakorolt hatásait már elkezdték vizsgálni. Az eddig javasolt új típusú zavarvédelem beépítése a már meglévő radarokba azonban túlságosan költséges. Új megoldásokra van szükség.

A légi forgalom növekedésével párhuzamosan egyre komolyabb jelentőséget kap a repülőterek körzetében a biztonságos légiközlekedést veszélyeztető hatások időbeni felderítése és költséghatékony kezelése. Jelenleg három polgári (Budapest, Sármellék, Debrecen), három katonai (Szolnok, Pápa, Kecskemét) és néhány ideiglenes repülőtér teljes légtér-irányítási funkcióit kell kiemelt biztonsággal, hatékonyan ellátni, illetve a felmerülő problémákat megoldani az új kihívások tükrében.

Napjaink radartechnológiája az új kihívásokat a radar adaptivitásának növelésével oldotta meg, de már megjelentek és a jövőben egyre nagyobb szerephez jutnak a radar szerves részét képező intelligens radarerőforrás-menedzsmentek. Ezek feladata, hogy az adaptív funkciók, részfeladatok végrehajtását a környezeti változások függvényében gyorsan átszervezzék, a meghibásodásokból adódó veszteségek hatását csökkentsék, ütemezzék az elvárt kalibrációs folyamatokat és hatékonyan elvégezzék azokat.

\section{LEHETŐSÉGEINK A HAZAI ÜZEMELTETÉSŰ RADAR PERFORMANCIÁK OPTIMALIZÁLÁSÁRA}

Történelmileg úgy alakult, hogy Magyarország az egyetlen NATO-ország, ahol a méteres (VHF) radarok folyamatos légtérellenőrzést végeznek. A VHF-radarok jelentőségét a többi NATO-tagország is kezdi felismerni, így figyelmet kell fordítanunk az új lengyel VHF-radar hazai alkalmazási lehetőségeinek felmérésére. (3. ábra) Külön figyelmet érdemel a francia Ground Master 400-as, amely az „S” frekvencia sávban üzemel és „mindent tud” amit egy mobil radarnak tudnia érdemes (4. ábra). A szerző véleménye szerint az antennafelület nagysága alapján az antennanyereség valószínűleg jelentősen behatárolja a „lopakodó” és egyéb kis RCS-szel rendelkező céltárgyak detektálhatóságát. Ez azért lehet probléma, mivel több feladat párhuzamos ütemezése esetén nem juthat elég idő a minőségi végrehajtásukra, így le kell mondani néhány feladatról, pl. a saját gépek követéséről. A román légierő számára leszállítandó „L" sávban üzemelő TPS-77-es mobil radar (5. ábra) nagyobb antennanyereséggel rendelkezik és ugyanúgy képes a harcászati ballisztikus rakéták detektálására és követésére, mint a Ground Master 400-as.

A légtérfelügyelettel kapcsolatos fejlődés része, hogy a magyar légtérellenőrzésre vonatkozó elvárások változnak. Amíg 1990-es évek közepén még reális elvárásnak tűntek a harcászati ballisztikus rakéták detektálásával kapcsolatos követelmények, addig ma már mások a prioritások. Ezek a kis magasságon repülő, kis visszaverő felülettel és nagy manőverező képességgel rendelkező drónok, valamint az alacsony - számunkra veszélyt jelentő Föld közeli - pályán keringő műholdak, kiemelt aktív és passzív zavarvédelmi képességek és a mobilitás. Ezek azok a tulajdonságok, amelyeket az alapfeladatok ellátásán túl, rövidesen implementálnunk kell a rádiólokációs rendszerünkbe. Ez a képesség az 1. ábrán bemutatott gaussi monostatikus rádiólokációs mérőpont napjaink technikai színvonalán történő kialakításával elérhető. [2] Ha a megoldás keresése 
közben költséghatékony logisztikával is szeretnénk rendelkezni, akkor a külföldi kínálatot ötvözni kell a hazai lehetőségekkel. Az 6. ábrán bemutatott radar még kísérleti stádiumban van, valós müszaki paraméterei ismeretlenek, ezért megengedhető, hogy e cikk szerzője elgondolkozzon azon, hogy milyen feladatokra tenné alkalmassá, ha lehetőséget kapna rá. Ránézésre megállapítható, hogy az antenna elemi sugárzói modulrendszerben vannak kialakítva, de az elemi sugárzók polarizációja lehet vízszintes, függőleges vagy akár a két polarizáció feladatfüggő keveréke. PI. vízszintes polarizáció a primer radar számára, míg néhány alrendszer függőleges polarizációt használ az SSR feladatok ellátására. Az antenna vízszintes mérete kb. fele a függőleges méretének, ezért joggal feltételezhető, hogy a vízszintes iránykarakterisztika szélesebb, mint a függőleges, így az antenna magasságmérési pontossága rendkívül nagy, míg oldalszögben több impulzust integrálhatunk koherensen. A sugárzók modulokba szervezése lehetőséget ad több feladat (pl. dróndetektálás, -követés, harcászati ballisztikus rakéta detektálása, követés, illetve alacsony pályán tartózkodó múholdkövetés) párhuzamos végrehajtására. A változó polarizációjú, az antennafelületen „véletlenszerüen" elhelyezkedő elemi sugárzók optimálisan helyezhetők el a legkülönbözőbb zavarvédelmi elvárások kielégítésére. Ha feltételezzük, hogy minden elemi sugárzó mögött saját, önállóan vezérelhető adó/vevő modul található, a rendszer szabadságfoka jóval meghaladhatja a napjainkban használt rádiólokátorok mérési szabadságfokát. A rendszer legfőbb problémáiának tűnik az adó-vevő modulok által előállított, kisugárzott és vett jelek közötti korreláció értékének növelése, hiszen a kölcsönhatások minimalizálásának lehetőségei végesek. Igaz, ma már aránylag olcsón kiépíthető optikai számítógépes hálózat a modulok között és akár atomórával is szinkronizálható a jelelőállítás, a jelfeldolgozás és a nagysebességű jelkalibrációs folyamatok. Mindenesetre nem látszik akadálya annak, hogy két ilyen antenna egymáshoz képest 200 m-re települjön és gaussi monostatikus formációban, párhuzamosan futó üzemmódokkal megduplázza a ma még ismeretlen performanciáját.

\section{Összegzés}

Történelmi tapasztalataink arra buzdítanak, hogy korunk kihívásaira újfajta megközelítésben keressük a megoldást. A cikk röviden áttekinti a közeljövő légtérellenőrzésével kapcsolatos kihívásokat és költséghatékony megoldást kínál a legsürgetőbb feladatokra. Eszerint a magyar légtérellenőrzésnek első fázisban 2 aktív fázisantennát kellene vásárolnia, amelyet a hazai szakemberek a meglévő kapacitásaikkal 1,5-2 év alatt minimális katonai képességekkel látnának el. Az ezt követő 1,5-2 évben a radarok elérnék a gaussi monosztatikus radarkonfiguráció nyújtotta képességeket. Ezt a feladatot el lehet kezdeni a VHF, „S” sávjában működő és a 6 . ábrán bemutatott radarantennákkal.

További kiemelt feladat, hogy lehetőséget kell teremteni a radarokkal foglalkozó mérnök-műszaki állomány tudásanyagának megtartására, elmélyítésére és az új, kidolgozás alatt lévő rendszerek performancia-vizsgálataira. Az új technológiák nyújtotta lehetőségek kihasználása a közfeladatok hatékonyabb ellátása érdekében indokolt, ezért vizsgálni kell a vonatkozó alkalmazási korlátokat, illetve az alkalmazások gazdaságos üzemeltetésének és megbízhatóságának kérdéseit. Az így megszerzett tudást be kell építeni a jövő rádiólokációs szakszolgálatának képzésébe.

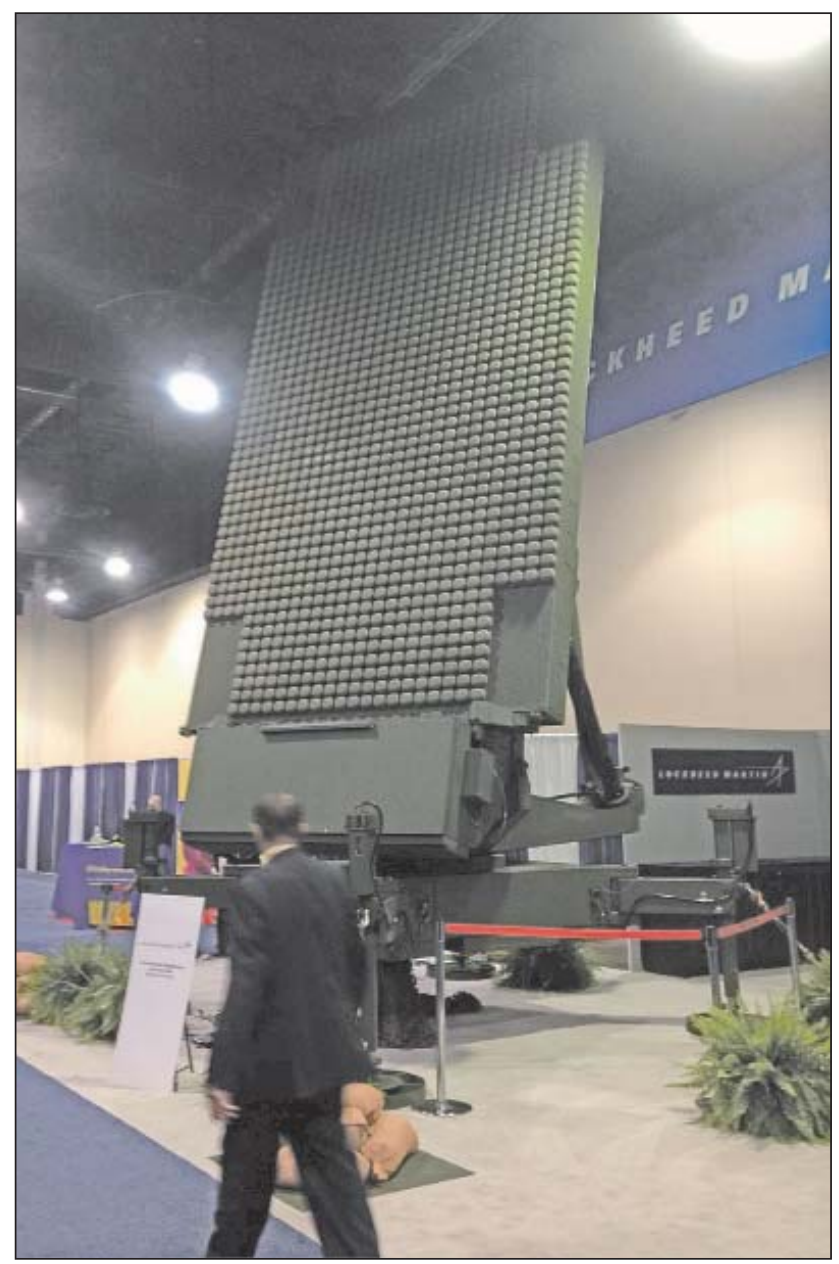

6. ábra. TPY-X mobil kísérleti radar

\section{IRODALOM}

1. I. Balajti, F. Hajdú: Surprising findings from the Hungarian radar developments in the era of the second world war, Radio Science Bulletin 358: (September) pp. 82-108.dokumentum típusa: Folyóiratcikk/Szakcikk nyelv: angol, http://www.ursi.org/content/RSB/

RSB_358_2016_09.pdf;

2. I. Balajti, Gy. Kende, Ed. Sinner: Increased importance of VHF radars in Ground - Based Air Defense, IEEE Aerospace and Electronic SYSTEMS Magazine, Januar 2012 p.2-18;

3. https://www.lockheedmartin.com/us/products/ ground-based-air-surveillance.html;

4. http://www.hmarzenal.hu/vedelmi-ipar/P-18MH2-radar. html;

5. http://www.bhe-mw.eu/ ;

6. https://propatria-inc.com/adaptive-multisensor-system;

7. http://www.sky-soft.hu/bemutatkozas.php;

8. https://www.thalesgroup.com/en/worldwide/defence/ ground-master-400-gm-400.

\section{JeGYZET}

1 (Az 1. ábrát, sokévi kutatás után, dr. Hajdú Ferenc mk. ezredes tárta fel. A magyar nyelvủ nyílt szakirodalomban most a Haditechnika közli első ízben. Szerk.) 